\title{
Seed Germination and Early Seedling Growth of Cynanchum bungei Decne (Asclepiadaceae) in Response to Photoperiod, Temperature, and Seed Size
}

\author{
Haiyan Zhang ${ }^{1}$ \\ College of Agronomy and Plant Protection/Shandong Key Laboratory of Dry \\ Farming Technique, Qingdao Agricultural University, Qingdao, Shandong, \\ 266109, P.R. China
}

Additional index words. Baishouwu, seed propagation, germination percentage, biomass, shoot, root

\begin{abstract}
Cynanchum bungei Decne is a rare, endemic, and important medicinal plant species in China. Seed germination and early seedling growth of large seeds (greater than $7 \mathrm{~mm}$ ) and small seeds (smaller than $7 \mathrm{~mm}$ ) were investigated at three temperatures $\left(15,20\right.$, and $\left.25^{\circ} \mathrm{C}\right)$ in both continuous light and alternating light/dark photoperiods to determine seed propagation requirements. Photoperiod significantly affected seed germination and early seedling growth. Germination and seedling growth at a 12:12-h photoperiod performed better than in continuous light. Temperature had a significant effect on germination index (GI), vigor index (VI), germination velocity (GV), mean germination time (MGT), shoot biomass (SB), root biomass (RB), and taproot length (TL), but no significant effect on final germination percentage (FGP). A temperature of $20{ }^{\circ} \mathrm{C}$ was the optimum temperature for seed germination and early seedling growth. Average growth height (AGH) and relative growth rate (RGR) of shoots at $15^{\circ} \mathrm{C}$ were greater than that at $20^{\circ} \mathrm{C}$. Large seeds had better germination and seedling performance than small seeds. However, small-seeded seedlings had greater biomass allocated to roots (BAR) and root-to-seedling ratio (RSR) than seedlings from large seeds. Small seeds of $C$. bungei could be more competent in unfavorable soil and light conditions than large seeds.
\end{abstract}

Cynanchum bungei Decne (Baishouwu in China), a member of the Asclepiadaceae family, is a perennial climbing shrub distributed in China. Its root has been used as a tonic medicine or health food for centuries in traditional Chinese medicine. C. bungei has useful activities including antitumor and immune regulatory effect and is non-toxic (Gao et al., 2005). As a rare, endemic, and beneficial species, $C$. bungei is becoming more and more precious not only in China, but also in other countries such as Japan and Korea (Song et al., 2006).

C. bungei is grown mainly by cuttings and root propagation and seldom by seed

\footnotetext{
Received for publication 28 Mar. 2012. Accepted for publication 26 June 2012.

I gratefully acknowledge Mark Goettel, Editor-inChief of Biocontrol Science \& Technology, for his critical revision of the manuscript; funding from National Natural Science Foundation of China (31101100), Shandong Distinguished Middle-aged and Young Scientist Encourage and Reward Foundation (BS2009NY034) and Basic Research Project of Qingdao Science and Technology Plan [11-2-4-5-(8)-jch], and Taishan Scholars Constructive Engineering Foundation of Shandong Province for financial support.

${ }^{1}$ To whom reprint requests should be addressed; e-mail hyzhang608@126.com.
}

between seed size and seed germination and seedling performance has been found within seed lots in a number of studies (Benard and Toft, 2007). In saline soils, smaller seeds of safflower and chickpea germinate faster and have better seedling performance compared with larger seeds (Farhoudi and Motamedi, 2010; Kaya et al., 2008). In different populations of the dimorphic Tragopogon pratensis subsp. pratensis, larger seeds yield higher germination percentage, yet no relationship has been found between seed size and seedling growth (Mölken et al., 2005).

Previous studies suggested that most of these factors show diverse effects on seed germination and seedling growth characteristics of different species. Information about C. bungei seed germination is lacking. The objectives of the study were to investigate seed germination and early seedling growth responses of $C$. bungei to photoperiod, temperature, and seed size to determine seed propagation requirements, develop standard germination procedures, and provide conservation strategies for $C$. bungei.

\section{Materials and Methods}

Seed source. Seeds of $C$. bungei were collected from the north-facing slope of Mount Tai (lat. $36^{\circ} 15^{\prime} 17^{\prime \prime} \mathrm{N}$, long. $117^{\circ} 06^{\prime} 15^{\prime \prime} \mathrm{E}$ ) in late fall and winter in 2010. Seeds were airdried at room temperature and stored in darkness at $4{ }^{\circ} \mathrm{C}$ until Mar. 2011.

Experimental procedures. Germination tests were performed from Mar. to May 2011. Seed length was measured manually and separated into two groups, i.e., small (less than $7 \mathrm{~mm}$ ) and large (greater than $7 \mathrm{~mm}$ ). Large and small seeds were immersed in $75 \%$ ethanol for $5 \mathrm{~min}$ and then 5\% sodium hypochlorite for 5 min for surface sterilization and then rinsed three times with deionized water and dried on filter paper.

The experiment was designed as a completely randomized factorial of two photoperiods, three temperatures, and two seed size treatments. Each treatment was replicated six times. Forty seeds per treatment were placed in a covered germination box $(13 \times$ $19 \times 12 \mathrm{~cm}$ ) containing $1200 \mathrm{~g}$ sterilized sand mixed with $187 \mathrm{~mL}$ deionized water. Seeds were germinated in incubators (HPG-280BX; Harbin Donglian Electronic Technology Development Ltd., Harbin, China) at 15 (T15), 20 (T20), and $25{ }^{\circ} \mathrm{C}$ (T25) in continuous light (Panasonic white fluorescent lamps, $234 \mu \mathrm{mol} \cdot \mathrm{m}^{-2} \cdot \mathrm{s}^{-1}, 580 \mathrm{~nm}$ ) (L24) and alternating 12-h light/12-h dark (L12) conditions.

The germinated seeds were recorded everyday for $20 \mathrm{~d}$. Seeds were considered to have germinated as soon as cotyledons emerged above the sand. Covers were removed when shoot length reached $5 \mathrm{~cm}$ in height. The seedlings were watered regularly. The germination boxes were rearranged daily to avoid effects of potential temperature and light differences or gradients in the incubators.

Germination performance was estimated according to the rate of germinated seeds. FGP is the rate of germinated seeds on the 
20th day. Germination index was GI $=\Sigma(\mathrm{Gt} / \mathrm{Tt})$, where Gt is the number of germinated seeds in Day $\mathrm{t}$ and $\mathrm{Tt}$ is the time corresponding to $\mathrm{Gt}$ in days. Vigor index was VI $=\mathrm{GI} \times$ shoot height on the 25th day. MGT was calculated according to $\mathrm{Hu}$ et al. (2005): $\mathrm{MGT}=\Sigma \mathrm{TiNi} /$ $\Sigma \mathrm{Ni}$, where $\mathrm{Ni}$ is the number of the newly germinated seeds in times of Ti. GV was estimated by using a modified Timson's (1965) index of germination through the expression: $\mathrm{GV}=\Sigma \mathrm{Gi} / \mathrm{Ti}$, where $\mathrm{i}$ is the number of counting periods at which the germination was evaluated, $\mathrm{Gi}$ is the percentage of germinated seeds in the i period, and Ti is the number of days since the initiation of the assay.

Shoot height (SH) was measured everyday for $25 \mathrm{~d}$. Average growth height of shoot: $\mathrm{AGH}=(\mathrm{SH}$ on 25 th day $-\mathrm{SH}$ on 20 th day $) / 5$; RGR (\%) was ( $\mathrm{SH}$ on the 25 th day $-\mathrm{SH}$ on the 20 th day) $/ \mathrm{SH}$ on the 20 th day $\times 100$. On the 25th day, we carefully uprooted the plant and washed the roots in a sieve with hole size of $1 \mathrm{~mm}$ and measured TL. RSR (\%) was TL/ $(\mathrm{TL}+\mathrm{SH}$ on the 25 th day $) \times 100$. The shoot and roots of each seedling were dried at $60{ }^{\circ} \mathrm{C}$ for $48 \mathrm{~h}$ to quantify SB and $\mathrm{RB}$. The percentage of BAR $(\%)$ was $\mathrm{RB} /(\mathrm{RB}+\mathrm{SB}) \times 100$.
Data analysis. FGP and BAR data were arsine transformed before statistical analysis to ensure homogeneity of variance. However, the original percentages are presented in the tables and figure. The germination and seedling growth characteristics were subjected to analysis of variance followed by Duncan's multiple range test using SPSS 11.5 software (SPSS Inc., Chicago, IL).

\section{Results}

Germination. Seeds began to germinate earlier and germination performance was better in $12 \mathrm{~h}$ light than continuous light (Table 1). The higher the temperature, the earlier seeds began to germinate. At 15, 20, and $25^{\circ} \mathrm{C}$, seeds began to germinate between the 12th to 14 th, 10th, and 8th to 9th day period, respectively. Overall, germination was greater at 20 than $15{ }^{\circ} \mathrm{C}$ but not well at $25^{\circ} \mathrm{C}$ after $14 \mathrm{~d}$ (Table 1). Except for the 14th to 17 th day period at $15{ }^{\circ} \mathrm{C}$ in continuous light, germination performance of large seeds was better than small seeds (Table 1).

Photoperiod and seed size had a significant effect on FGP. FGP was significantly higher in $12 \mathrm{~h}$ light than continuous light and large seeds than small seeds (Table 2). Temperature had no significant effect on FGP (Table 2)

Photoperiod, temperature, and seed size had significant effects on GI, VI, GV, and MGT. GI, VI, and GV were significantly higher in $12 \mathrm{~h}$ light than continuous light, high temperature than low temperature, and large seeds than small seeds (Table 2). MGT was significantly shorter in $12 \mathrm{~h}$ light than continuous light, high temperature than low temperature, and large seeds than small seeds (Table 2).

Seedling growth. Because the shoots at $25{ }^{\circ} \mathrm{C}$ wilted from the 16 th day, $\mathrm{SH}$ was not determined after $16 \mathrm{~d}$ at $25{ }^{\circ} \mathrm{C}$. A high temperature $\left(25^{\circ} \mathrm{C}\right)$ was not favorable for seedling growth and was excluded from the seedling growth analysis. Overall, $\mathrm{SH}$ was much higher at $20^{\circ} \mathrm{C}$ than $15^{\circ} \mathrm{C}$ and in $12 \mathrm{~h}$ light than continuous light (Table 3). Except for the 14th to 18 th day period at $15{ }^{\circ} \mathrm{C}$ in continuous light, $\mathrm{SH}$ of large seeds was higher than that of small seeds. Overall, both AGH and RGR of shoot were higher at 15 than $20{ }^{\circ} \mathrm{C}$, in $12 \mathrm{~h}$ light than continuous light, and large seeds than small seeds in the early seedling stage.

Table 1. Germination performance of large and small seeds in C. bungei at 15 (T15), 20 (T20), and $25{ }^{\circ} \mathrm{C}$ (T25) in alternating $12 \mathrm{~h}$ light/12 h dark (L12) and continuous light (L24).

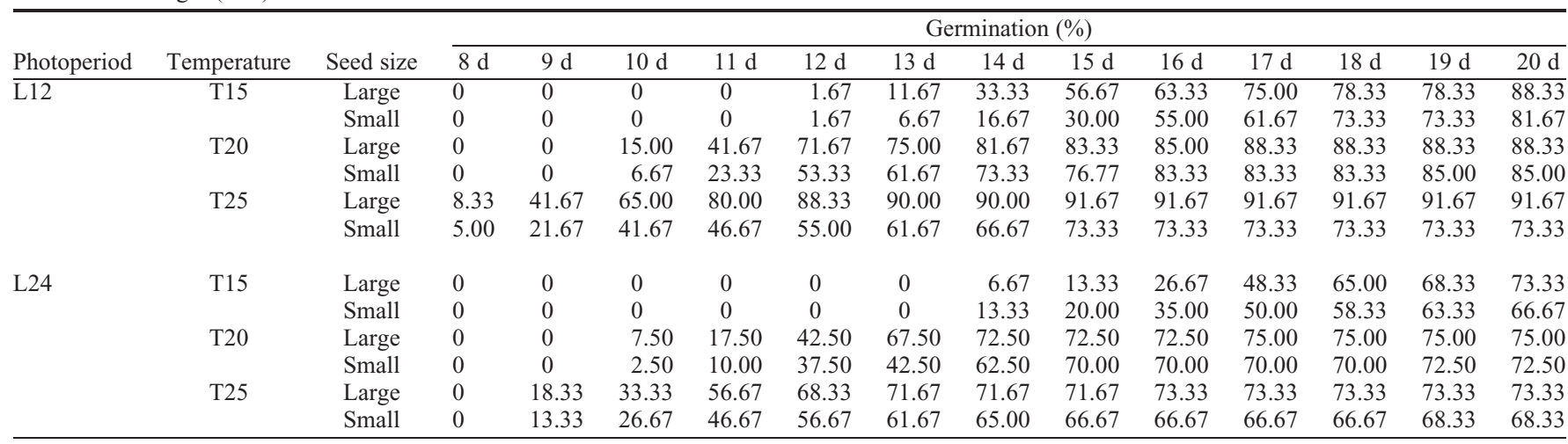

Table 2. Final germination percentage (FGP), germination index (GI), vigor index (VI), germination velocity (GV), and mean germination time (MGT) of large and small seeds in C. bungei at 15 (T15), 20 (T20), and $25^{\circ} \mathrm{C}$ (T25) in alternating $12 \mathrm{~h}$ light/12 h dark (L12) and continuous light (L24).

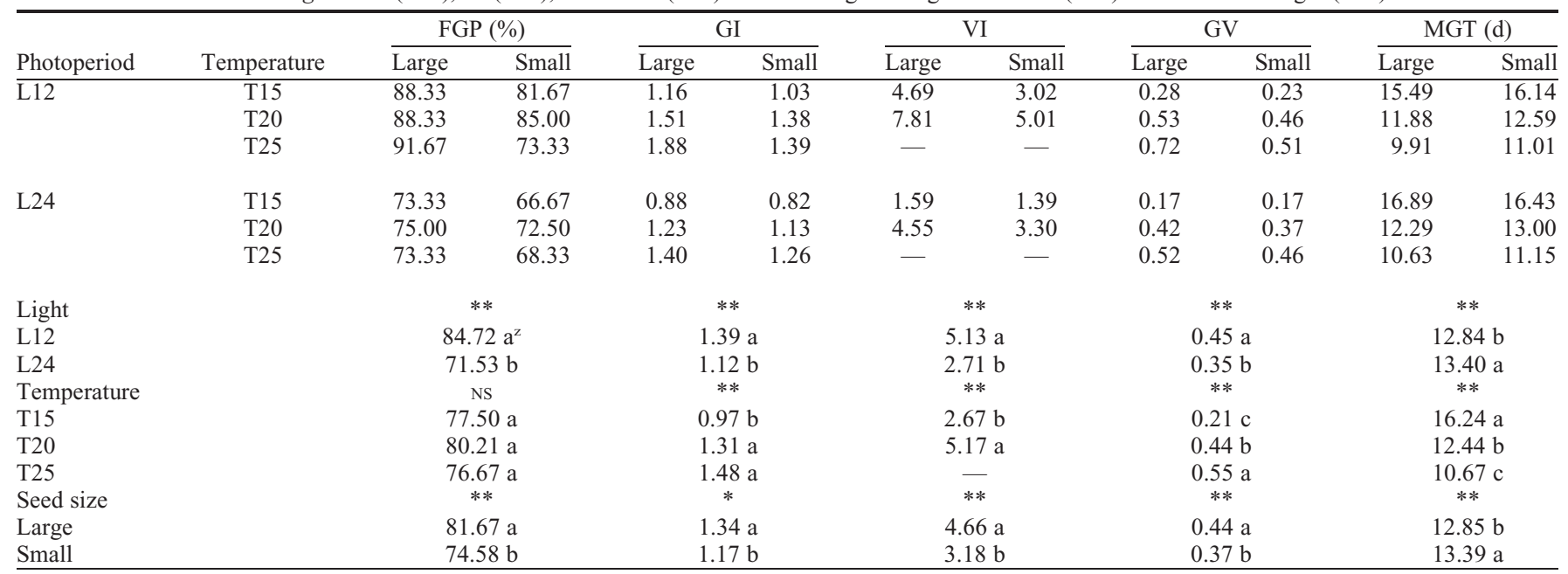

${ }^{2}$ Within a factor and column, values followed by different letters are significantly different $(P \leq 0.05)$.

Ns, *,**Nonsignificant or significant at $P \leq 0.05$, or 0.01 , respectively. 


\begin{tabular}{|c|c|c|c|c|c|c|c|c|c|c|c|c|c|c|c|c|c|c|c|c|c|c|}
\hline \multirow[b]{2}{*}{ Photoperiod } & \multirow[b]{2}{*}{ Temperature } & \multirow[b]{2}{*}{ Seed size } & \multicolumn{18}{|c|}{$\mathrm{SH}(\mathrm{cm})$} & \multirow{2}{*}{$\begin{array}{l}\mathrm{AGH} \\
(\mathrm{cm})\end{array}$} & \multirow{2}{*}{$\begin{array}{c}\text { RGR } \\
(\%)\end{array}$} \\
\hline & & & $8 \mathrm{~d}$ & $9 \mathrm{~d}$ & $10 \mathrm{~d}$ & $11 \mathrm{~d}$ & $12 \mathrm{~d}$ & $13 \mathrm{~d}$ & $14 \mathrm{~d}$ & $15 \mathrm{~d}$ & $16 \mathrm{~d}$ & $17 \mathrm{c}$ & $18 \mathrm{~d}$ & $19 \mathrm{~d}$ & $20 \mathrm{~d}$ & $21 \mathrm{~d}$ & $22 \mathrm{~d}$ & $23 \mathrm{~d}$ & $24 \mathrm{~d}$ & $25 \mathrm{~d}$ & & \\
\hline & & Small & 0 & 0 & 0 & 0 & 0.01 & 0.04 & 0.11 & 0.15 & 0.43 & 0.62 & 0.90 & 1.08 & 1.58 & 1.89 & 2.20 & 2.58 & 2.66 & 2.93 & 0.27 & 85.44 \\
\hline & T20 & Large & 0 & 0 & 0.12 & 0.37 & 0.87 & 1.35 & 1.82 & 2.32 & 2.75 & 3.25 & 3.73 & 3.96 & 4.33 & 4.47 & 4.73 & 4.92 & 5.08 & 5.16 & 0.17 & 19.17 \\
\hline & T25 & Large & 0.08 & 0.49 & 1.18 & 1.87 & 2.53 & 3.11 & 3.56 & 4.04 & 4.30 & - & - & - & - & - & - & - & - & - & - & - \\
\hline & & Small & 0.02 & 0.19 & 0.56 & 0.82 & 1.07 & 1.46 & 1.72 & 1.98 & 2.13 & - & - & - & - & - & - & - & - & - & - & - \\
\hline & T20 & Large & 0 & 0 & 0.02 & 0.08 & 0.47 & 0.97 & 1.60 & 1.89 & 2.08 & $2.4 \mathrm{C}$ & 2.81 & 3.04 & 3.12 & 3.26 & 3.35 & 3.53 & 3.76 & 3.89 & 0.15 & 24.68 \\
\hline & & Small & 0 & 0 & 0.02 & 0.09 & 0.39 & 0.65 & 1.16 & 1.49 & 1.63 & 1.80 & 2.11 & 2.42 & 2.49 & 2.59 & 2.65 & 2.73 & 2.86 & 2.91 & 0.08 & 16.87 \\
\hline & $\mathrm{T} 25$ & Large & 0 & 0.15 & 0.47 & 0.92 & 1.70 & 2.07 & 2.53 & 2.69 & 2.76 & - & - & - & - & - & - & - & - & - & - & - \\
\hline & & Small & 0 & 0.09 & 0.34 & 0.65 & 1.13 & 1.44 & 1.80 & 1.98 & 1.99 & - & - & - & - & - & - & - & - & - & - & - \\
\hline
\end{tabular}

Photoperiod, temperature, and seed size had a significant effect on SB, RB, and TL. $\mathrm{SB}, \mathrm{RB}$, and TL were significantly greater in $12 \mathrm{~h}$ light than continuous light, at 20 than $15{ }^{\circ} \mathrm{C}$, and large seeds than small seeds (Fig. 1A-C). Nevertheless, seedlings derived from small seeds allocated more plant biomass to roots ( small seeds $=35.34 \% \pm 3.39 \%$, large seeds $=31.19 \% \pm 5.18 \% ; \mathrm{F}=28.43, P<$ 0.0001 ; Fig. 1D) and developed roots with greater RSR (small seeds $=61.65 \% \pm 4.22 \%$, large seeds $=58.72 \% \pm 3.84 \% ; \mathrm{F}=14.44, P=$ $0.00157)$ than those germinating from large seeds.

\section{Discussion}

Plants vary in their response to light during seed germination (Baskin and Baskin, 1998). This study showed that germination characteristics and seedling growth were better in alternating light/dark than in continuous light at all temperatures tested (Tables 1, 2, and 3; Fig. 1), indicating that continuous light can inhibit seed germination and seedling growth of $C$. bungei. In this sense, presence of dark enhances seed germination and seedling growth of this species. The inhibition of continuous light on germination characteristics and seedling growth of large seeds was greater than that of small seeds, indicating that small seeds are more competent in unfavorable light conditions.

In this study, temperature had a significant effect on GI, VI, GV, and MGT but no significant effect on FGP (Table 2). High temperature enhanced GV, advanced germination initiation time, and shortened MGT, but germination and seedling performance at $25^{\circ} \mathrm{C}$ was not satisfactory (Tables 1 and 3 ). The optimum temperature for seed germination and early seedling growth of $C$. bungei was $20^{\circ} \mathrm{C}$. However, $15{ }^{\circ} \mathrm{C}$ treatment had greater AGH and RGR of shoot compared with $20{ }^{\circ} \mathrm{C}$ treatment (Table 3 ). The experiment would have to be repeated with a longer duration of time before we could conclude with confidence whether 15 or $20^{\circ} \mathrm{C}$ is the optimal temperature in the whole seedling stage. Temperature shifts may affect a number of processes determining the germinability of seeds, including membrane permeability, activity of membrane-bound

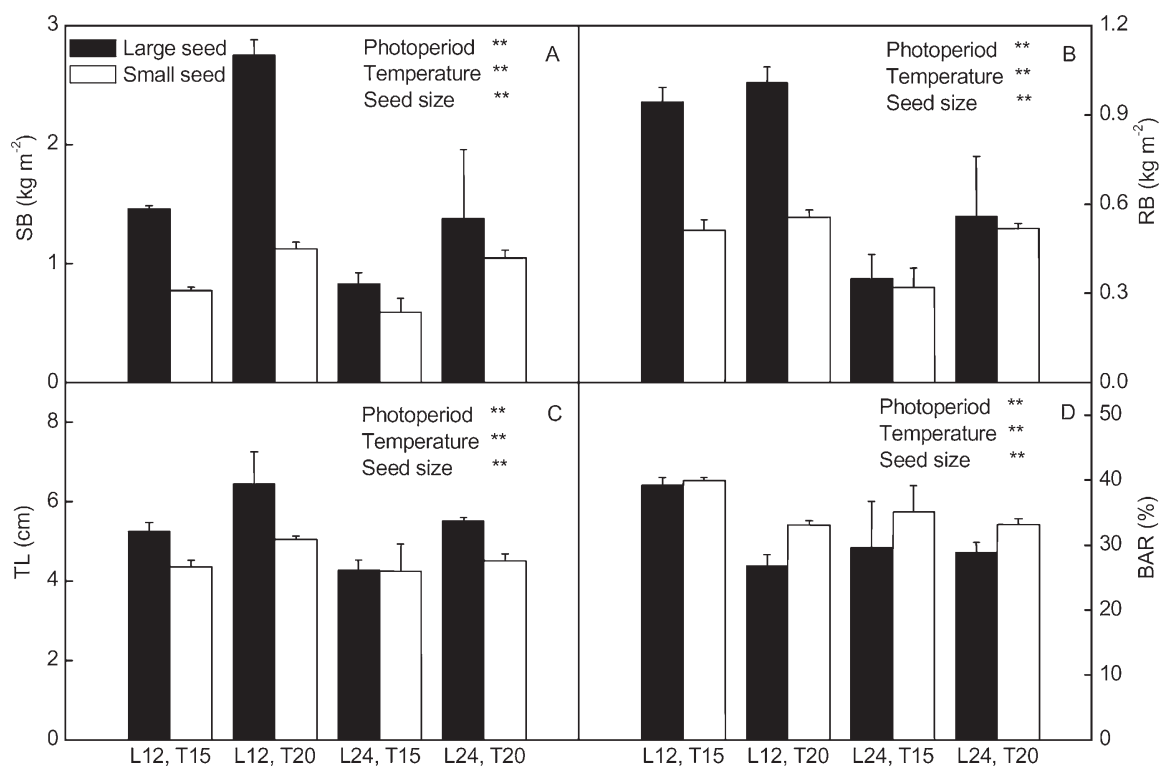

Fig. 1. Shoot biomass (SB) (A); root biomass (RB) (B); taproot length (TL) (C); and the percentage of biomass allocated to root (BAR) (D) of large and small seeds in C. bungei at 15 (T15) and $20^{\circ} \mathrm{C}(\mathrm{T} 20)$

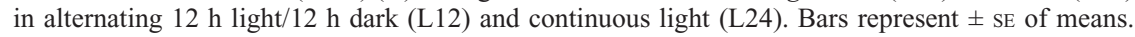
** Significant at $P \leq 0.01$.

proteins, and cytosol enzymes (Bewley and Black, 1994). In the future, alternating temperature regimes should be considered to further elucidate temperature effects on germination of this species.

Recently, the effects of seed size variation on seed germination and seedling growth have received great attention (Benard and Toft, 2007; Bretagnolle et al., 1995; Mohsen et al., 2011; Moles and Westoby, 2004). There is positive (Mölken et al., 2005), negative (Benard and Toft, 2007; Kaya et al., 2008; Rebecca, 1984; Susko and Lovett-Doust, 2000) or no relationship (Boyle and Hladun, 2005) between seed size and germination performance. In this study, large seeds had higher FGP, GI, VI, GV, SB, RB, TL, and shorter MGT. The author inferred that either embryo size or endosperm content could differ between large and small $C$. bungei seeds. Some authors hypothesized that large seeds enable seedling to allocate proportionally more resources to root development than small seeds (Baker, 1972; Stebbins, 1971).
If this hypothesis stands, then seed size should be positively correlated with the allocation percentage of biomass to root system (Leishman and Westoby, 1994), but evidence to support this hypothesis has been limited (Benard and Toft, 2007). In this study, smallseeded seedlings had a significantly greater BAR and RSR in contrast with other studies that have detected a positive (Benard and Toft, 2007; Leishman and Westoby, 1994) or no relationship (Jurado and Westoby, 1992; Wulff, 1986) between seed size and allocation to root systems. The greater BAR and RSR would be advantageous for small seeds of $C$. bungei to grow in unfavorable soils with high $\mathrm{pH}$, little water, and low nutrients, etc.

\section{Conclusion}

Seed propagation is a valuable method for the reproduction and conservation of $C$. bungei and thereby expand genetic variability. We found that alternating light/dark and $20{ }^{\circ} \mathrm{C}$ are appropriate requirements for 
C. bungei seed germination. Large seeds have a higher germinability than small seeds; however, small seeds could be more competent in unfavorable conditions.

\section{Literature Cited}

Baker, H.G. 1972. Seed weight in relation to environmental conditions in California. Ecology 53:997-1010.

Baskin, C.C. and J.M. Baskin. 1998. Seeds: Ecology, biogeography, and evolution of dormancy and germination. Academic Press, San Diego, CA.

Benard, R.B. and C.A. Toft. 2007. Effect of seed size on seedling performance in a longlived desert perennial shrub (Ericameria nauseosa: Asteraceae). Intl. J. Plant Sci. 168:1027-1033.

Bewley, J.D. and M. Black. 1994. Seeds: Physiology of development and germination. Plenum Press, New York, NY.

Boyle, T.H. and K. Hladun. 2005. Influence of seed size, testa color, scarification method, and immersion in cool or hot water on germination of Baptisia australis (L.) R. Br. seeds. HortScience 40:1846-1849

Bretagnolle, F., J.D. Thompson, and R. Lumaret. 1995. The influence of seed size variation on seed germination and seedling vigour in diploid and tetraploid Dactylis glomerata L. Ann. Bot. (Lond.) 76:607-615.

Cuzzuol, G.R.F. and N.M.C. Lucas. 1999. Seed germination in Matelea maritima (Jack.) woods (Asclepiadaceae). Rev. Bras. Bot. 22:1-7.

Farhoudi, R. and M. Motamedi. 2010. Effect of salt stress and seed size on germination and early seedling growth of safflower (Carthamus tinctorius L.). Seed Sci. \& Technol. 38:73-78.

Gao, L.J., J.H. Wang, J.H. Cui, and H.Z. Wang. 2005. Studies on immunoregulation of polysaccharides1a from Radix Cynanchi Bungei. China J. Chin. Mater. Med. 30:1352-1355.

Hu, J., Z.Y. Zhu, W.J. Song, J.C. Wang, and W.M Hu. 2005. Effects of sand priming on germination and field performance in direct-sown rice (Oryza sativa L.). Seed Sci. \& Technol. 33:243-248.

Jurado, E. and M. Westoby. 1992. Seedling growth in relation to seed size among species of arid. Aust. J. Ecol. 80:407-416.

Kaya, M., G. Kaya, M.D. Kaya, M. Atak, S. Saglam, K.M. Khawar, and C.Y. Ciftci. 2008. Interaction between seed size and $\mathrm{NaCl}$ on germination and early seedling growth of some Turkish cultivars of chickpea (Cicer arietinum L.). J. Zhejiang Univ. Sci. B 5:371-377.

Leishman, M.R. and M. Westoby. 1994. The role of seed size in seedling establishment in dry soil conditions-Experimental evidence from semi-arid species. J. Ecol. 82:249-258.

Mohsen, M.N., B. Mahdi, and T. Abolfazl. 2011 Effect of seed size and genotype on germination characteristic and seed nutrient content of wheat. Sci. Res. Essay. 6:2019-2025.

Moles, A.T. and M. Westoby. 2004. Seedling survival and seed size: A synthesis of the literature. J. Ecol. 92:372-383.

Mölken, T.V., L.D. Jorritsma-Wienk, P.H.W.V. Hoek, and H.D. Kroon. 2005. Only seed size matters for germination in different populations of the dimorphic Tragopogon pratensis subsp. Pratensis (Asteraceae). Amer. J. Bot. 3:432437.
Norman, C.D. 1993. Seed germination, theory and practice, 2nd ed; (1996) First supplement; (1998) Second supplement. Norman, C.D. State College, PA.

Rebecca, W.D. 1984. The effect of seed size and maternal source on individual size in a population of Ludwigia leptocarpa (Onagraceae). Amer. J. Bot. 71:1302-1307.

Sen, D.N. 1968. Ecology of desert plants and observations on their seedlings. II. Germination behaviour of seeds in Asclepiadaceae. Österr. Bot. Z. 115:18-27.

Smith, H. 1982. Light quality, photoperception, and plant strategy. Annu. Rev. Plant Physiol. 33:481-518.

Song, Z.G., J.H. Wang, H.Z. Wang, A.H. Zhao, C.X. Liu, and J.C. Tian. 2006. Some properties of starch isolated from Radix Cynanchi bungei. Starch-Stärke 58:243-248.

Stebbins, G.L. 1971. Adaptive radiation of reproductive characteristics in angiosperms, II Seeds and seedlings. Annu. Rev. Ecol. Syst 2:237-260.

Susko, D.J. and L. Lovett-Doust. 2000. Patterns of seed mass variation and their effects on seedling traits in Alliaria petiolata (Brassicaceae). Amer. J. Bot. 87:56-66.

Timson, J. 1965. New method of recording germination data. Nature 207:216-217.

Wulff, R.D. 1986. Seed size variation in Desmodium paniculatum. II. Effects on seedling growth and physiological performance. J. Ecol. 74: 99-114

Zhang, F., S.L. Yu, and J.H. Wang. 2010. Studies on the photosynthetic characteristics and its relationship to yield in Radix Cynanchum bungei Decne. J. Nuclear Agr. Sci. 24:176-180. 